\title{
No Evidence of Coronaviruses or Other Potentially Zoonotic Viruses in Sunda pangolins (Manis javanica) Entering the Wildlife Trade via Malaysia
}

\author{
Jimmy Lee, ${ }^{1,2}$ Tom Hughes, ${ }^{1,2}$ Mei-Ho Lee, ${ }^{1,2}$ Hume Field, ${ }^{1}$ Jeffrine Japning Rovie-Ryan, ${ }^{3}$ \\ Frankie Thomas Sitam, ${ }^{3}$ Symphorosa Sipangkui, ${ }^{4}$ Senthilvel K. S. S. Nathan, ${ }^{4}$ \\ Diana Ramirez, ${ }^{4}$ Subbiah Vijay Kumar, ${ }^{5}$ Helen Lasimbang, ${ }^{6}$ Jonathan H. Epstein, ${ }^{1}$ \\ and Peter Daszak ${ }^{1}$ \\ ${ }^{1}$ EcoHealth Alliance, 520 Eighth Avenue, Suite 1200, New York, NY 10018 \\ ${ }^{2}$ Conservation Medicine, Unit $13 \mathrm{H}$ Villamas, Jalan Villamas, 47000 Sungai Buloh, Selangor, Malaysia \\ ${ }^{3}$ National Wildlife Forensic Laboratory, Department of Wildlife and National Parks (PERHILITAN), Peninsular Malaysia, KM 10, Jalan Cheras, \\ 56100 Kuala Lumpur, Malaysia \\ ${ }^{4}$ Sabah Wildlife Department, 5th Floor, B Block, Wisma MUIS, 88100 Kota Kinabalu, Sabah, Malaysia \\ ${ }^{5}$ Biotechnology Research Institute, Universiti Malaysia Sabah, Jalan UMS, 88400 Kota Kinabalu, Sabah, Malaysia \\ ${ }^{6}$ Faculty of Medicine and Health Sciences, Universiti Malaysia Sabah, Jalan UMS, 88400 Kota Kinabalu, Sabah, Malaysia
}

\begin{abstract}
The legal and illegal trade in wildlife for food, medicine and other products is a globally significant threat to biodiversity that is also responsible for the emergence of pathogens that threaten human and livestock health and our global economy. Trade in wildlife likely played a role in the origin of COVID-19, and viruses closely related to SARS-CoV-2 have been identified in bats and pangolins, both traded widely. To investigate the possible role of pangolins as a source of potential zoonoses, we collected throat and rectal swabs from 334 Sunda pangolins (Manis javanica) confiscated in Peninsular Malaysia and Sabah between August 2009 and March 2019. Total nucleic acid was extracted for viral molecular screening using conventional PCR protocols used to routinely identify known and novel viruses in extensive prior sampling ( $>50,000$ mammals). No sample yielded a positive PCR result for any of the targeted viral families - Coronaviridae, Filoviridae, Flaviviridae, Orthomyxoviridae and Paramyxoviridae. In the light of recent reports of coronaviruses including a SARS-CoV-2-related virus in Sunda pangolins in China, the lack of any coronavirus detection in our 'upstream' market chain samples suggests that these detections in 'downstream' animals more plausibly reflect exposure to infected humans, wildlife or other animals within the wildlife trade network. While confirmatory serologic studies are needed, it is likely that Sunda pangolins are incidental hosts of coronaviruses. Our findings further support the importance of ending the trade in wildlife globally.
\end{abstract}

Keywords: Sunda pangolins, SARSr-CoV, Malaysia, COVID-19, Zoonotic viruses, Coronavirus, Wildlife trade

\section{INTRODUCTION}

Diana Ramirez deceased on 31st October 2018.

Published online: November 23, 2020

Correspondence to: Jimmy Lee, e-mail: jimmy@ecohealthalliance.org
The legal and illegal trade in wildlife for consumption as food, medicine and other products is a globally significant threat to 
conservation (Smith et al. 2006; Nayar 2009; Rosen and Smith 2010). It also drives the emergence of pathogens that threaten human and domestic animal health, and national and global economies (Lee and McKibbin 2004; Smith et al. 2008, 2009). This includes the 2003 Severe Acute Respiratory Syndrome (SARS) outbreak caused by SARS coronavirus (SARS-CoV), which originated in the large wet markets of Guangdong province, China (Ksiazek et al. 2003), and the current COVID-19 outbreak caused by SARS-CoV-2, first discovered in people associated with a wet market in Wuhan (Zhou et al. 2020; Zhu et al. 2020). Both viruses likely originated in bats, with SARS$\mathrm{CoV}$ infecting civets and other small mammals in the markets, which may have acted as intermediate or amplifying hosts (Guan et al. 2003; Wang and Eaton 2007). The finding of furin cleavage insertions in the spike (s) protein sequence in the SARS-CoV-2 genome has led some to suggest that intermediate hosts may have been involved in the emergence of COVID-19 (Andersen et al. 2020); however, no intermediate hosts have so far been conclusively identified. Recently, four different groups have identified coronaviruses in imported Sunda or Malayan pangolins (Manis javanica) seized in raids on wildlife traders in China (Liu et al. 2019; Lam et al. 2020; Xiao et al. 2020; Zhang et al. 2020). The genomes of these are closely related to SARS$\mathrm{CoV}-2$, particularly in some genes, including the s-gene responsible for binding to host cells, albeit that some bat-CoVs have higher overall sequence identity to SARS-CoV-2 (Latinne et al. 2020). Authors of these papers propose that further sampling of pangolins might help elucidate the potential role of pangolins in the evolution of SARSr-CoVs, the emergence of COVID-19, and the risk of future zoonotic viral emergence (Liu et al. 2020; Lam et al. 2020; Xiao et al. 2020).

Over a ten-year period, as part of the USAID PREDICT project (PREDICT Consortium 2017; PREDICT Consortium 2019), we collected biological samples from confiscated and rescued Sunda pangolins in their country of origin: Peninsular Malaysia and the Malaysian state of Sabah on the island of Borneo. The aims of this study were to identify the phylogeographic origins of confiscated pangolins and any potentially zoonotic pathogens associated with them (Karesh 2010). Here, we report on the results from pathogen surveillance and discovery screening of these pangolin samples.

\section{Materials And Methods}

Sunda pangolins (Manis javanica) were either confiscated from smugglers or rescued from the wild between August
2009 and March 2019 and were in the possession of the Department of Wildlife and National Parks Peninsular Malaysia, or Sabah Wildlife Department at the time of sampling or Sabah Wildlife Department at the time of sampling (Figs. 1, 2, 3). Most confiscations occurred near national borders or ports and were reported to be destined for other Southeast Asian countries en route to China and were usually found in sacks or crates in temporary holding facilities, or in vehicles. The wild-rescued Sunda pangolins were all surrendered by members of the public who found them in their native habitats. All pangolins were alive during the sampling process; based on their weakened condition, it appeared that some had been in captivity for many weeks, although we were unable to confirm this.

The sampling protocol was approved by UC DAVIS Institutional Animal Care and Use Committee (protocol number: 16048). Each pangolin was assigned a unique identification code; GPS coordinates of the confiscation or rescue locations, biometric measurement and physical health check information were recorded. Swab samples were collected from the throat and rectum using a sterile non-absorbent mini-tip polyester swab (Puritan, Guilford, USA) placed in a cryotube contained $600 \mu \mathrm{L}$ of TRIzol reagent (Invitrogen, Carlsbad, USA) to maintain RNA integrity. All samples were stored at $-196^{\circ} \mathrm{C}$ immediately after collection (typically within $10 \mathrm{~min}$ ) in a liquid nitrogen dewar MVE Doble 34 (Chart Biomed, Ball Ground, USA) in the field and transferred to a $-80^{\circ} \mathrm{C}$ freezer for long-term storage on return to the laboratory. Cold chain integrity in storage was ensured by carbon dioxide monitoring, temperature monitoring, and a backup generator system, consistent with certified BSL-2 laboratory requirements.

Total nucleic acid was extracted for viral molecular screening using the NUCLISENS EASYMAG or MINIMAG system according to the manufacturer's protocol with validated modifications (bioMérieux, Marcy l'Etoile, France). The purity and concentration of extracted RNA were assessed using the Nanodrop 2000 spectrophotometer (Thermo Scientific, Massachusetts, USA). Complementary DNA (cDNA) of each sample was generated, according to manufacturer's protocol with random hexamers, from the SuperScript III First-Strand Synthesis System for reverse transcription PCR (Invitrogen, Carlsbad, USA). cDNA synthesis control from the kit was performed as per manufacturer's protocol using the control RNA and the control sense and control antisense primers. The synthesized cDNA was validated with PCR targeting the cytochrome c oxidase 


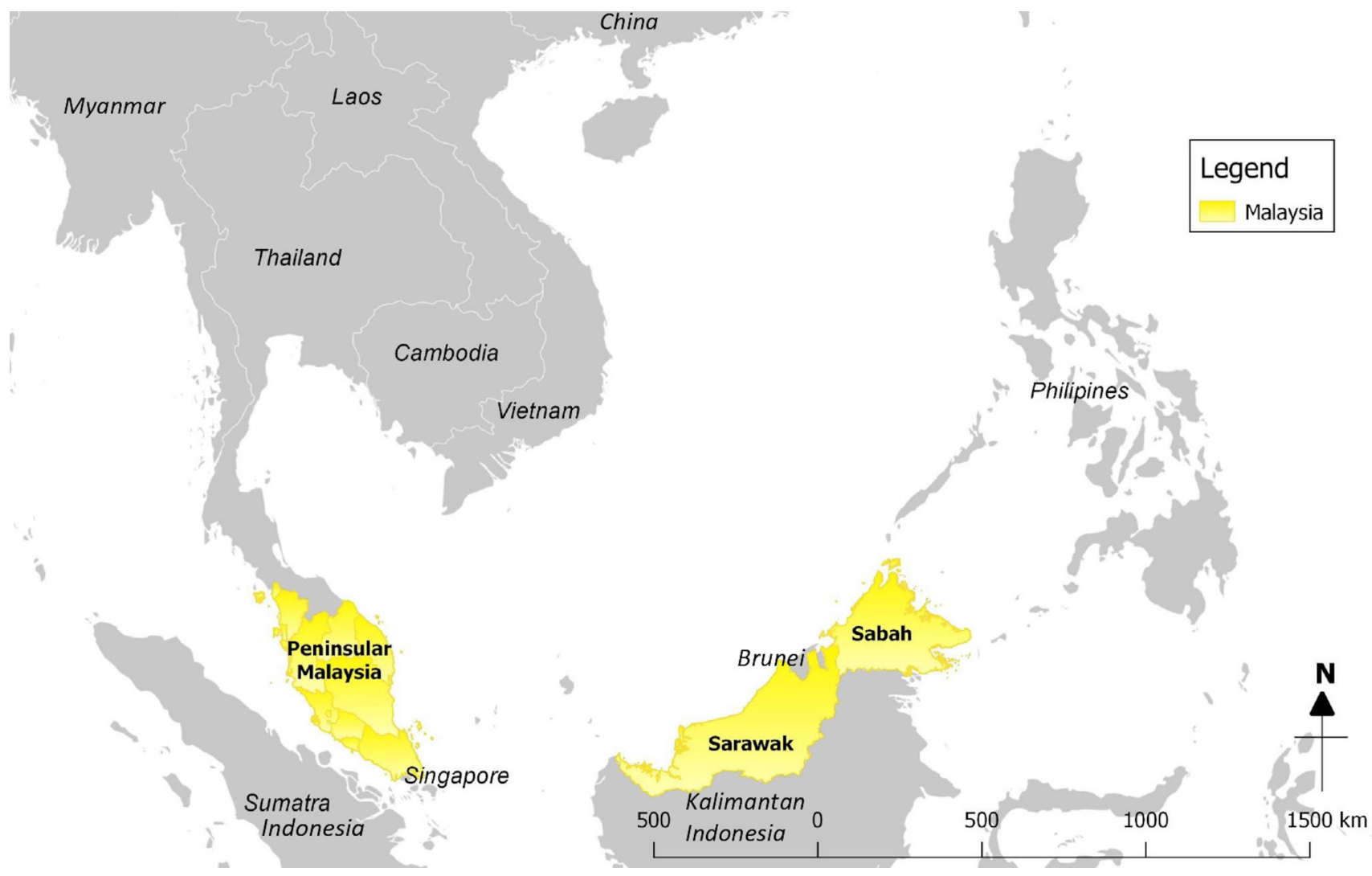

Figure 1. Map of Southeast Asia and China.

subunit I (CO1) gene and the cytochrome b (Cytb) mitochondrial gene (Table 1). The cDNA was used in conventional PCR protocols screening five viral families: Coronaviridae, Filoviridae, Flaviviridae, Orthomyxoviridae and Paramyxoviridae (Table 1). The PCRs were conducted in a Veriti or SimpliAmp thermal cycler (Applied Biosystems, Foster City, USA). Reactions were carried out in a final volume of $20 \mu \mathrm{l}$, following the manufacturer's protocol (Qiagen, Hilden, Germany) using $1 \mu \mathrm{l}$ of the cDNA product as a template and either Fast-Cycling PCR kit or HotStarTaq Plus Master Mix with a final concentration of $0.1 \mu \mathrm{M}$ for each primer following the manufacturer's protocols (Qiagen, Hilden, Germany). PREDICT universal controls 1 and 2 (Anthony et al. 2013) and specific controls for Filovirus (One Health Institute Laboratory, University of California, Davis) and Influenza Liang PCR (Liang et al., unpublished) were used. Peninsular Malaysia and Sabah samples were screened on separate occasions at two different certified BSL2 biocontainment level laboratories using standardised methods. PCR products were loaded and run on $1 \%$ agarose gel electrophoresis $-100 \mathrm{~V}$, for 30-45 min with $0.5 \times$ tris-acetate-EDTA buffer (Vivantis Technologies Sdn. Bhd., Subang Jaya, Malaysia). The gels were viewed on a transilluminator, and expected size bands were excised and stored in separate microcentrifuge tubes, and the corresponding post-PCR mixes were used as a template for contamination control PCRs to check for contamination from the universal positive controls. PCR products were run under the same gel electrophoresis conditions; those without the expected size bands showed that there was no contamination from the controls. Products from the initial PCR of these samples were then purified using the Ultrafree-DA centrifugal filter units (Millipore, Cork, Ireland); the purified products were cloned using the dual-colour selection Strataclone PCR cloning kit according to the manufacturer's protocol (Stratagene, La Jolla, USA). Up to eight colonies containing the PCR product were selected and inoculated on LuriaBertani agar slants, individually. Grown colonies were sent to a commercial company for direct colony sequencing. 


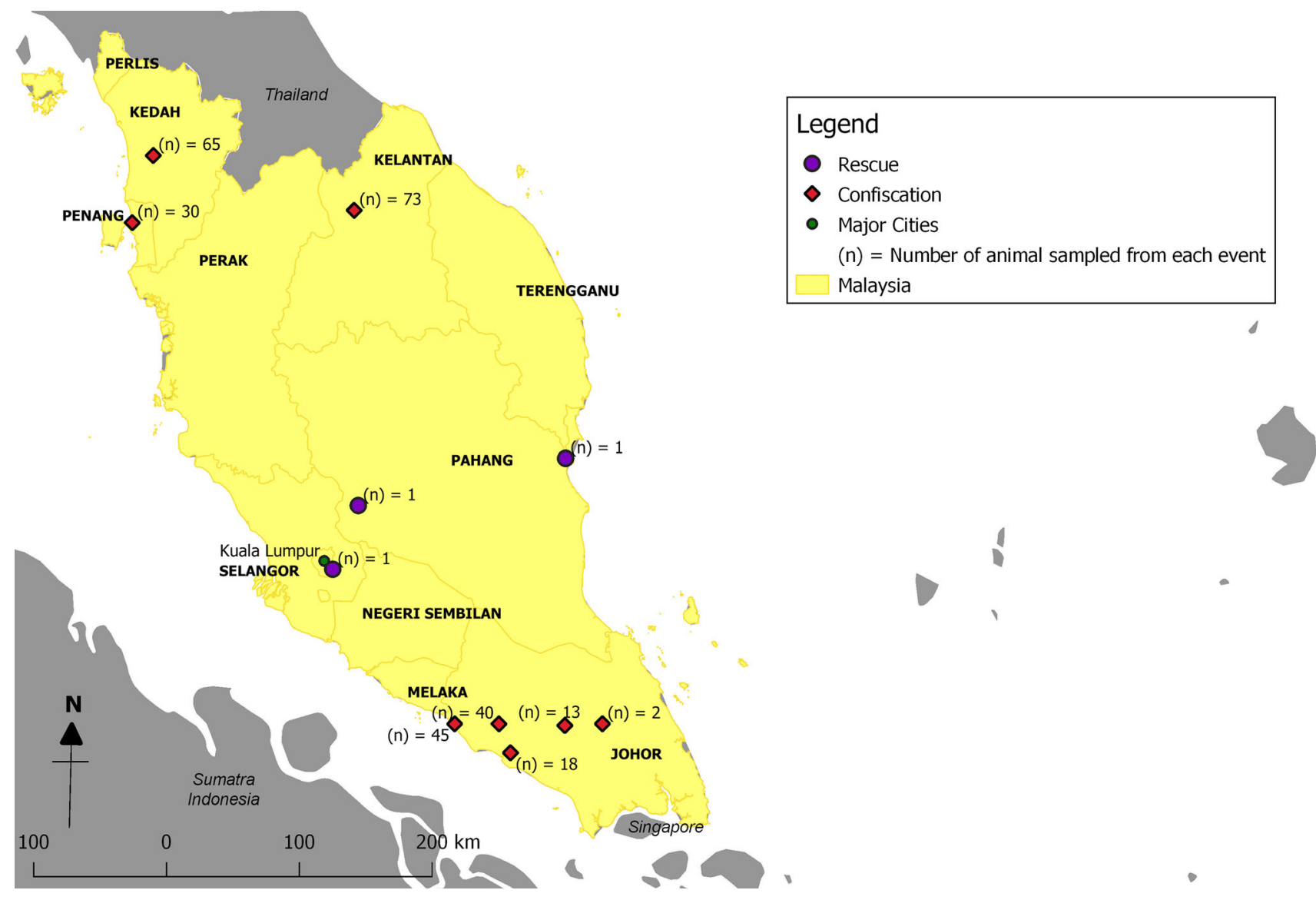

Figure 2. Locations where pangolins were rescued and confiscated in Peninsular Malaysia.

\section{Results}

A total of 334 Sunda pangolins were screened: 289 in Peninsular Malaysia (confiscated $n=286$; wild-rescued $n=3$ ) (Table 2a, b) and 45 in Sabah state (confiscated $n=40$; wild-rescued $n=5$ ) (Table $2 \mathrm{c}$, d). No sample yielded a positive PCR result for any member of the targeted virus families, either in Peninsular Malaysia (95\% CI $0.0-0.01$ ) or in Sabah (95\% CI 0.0-0.08). RNA extracted from the samples had low purity and concentration (Table 3); however, both the CO1 gene (Fig. 4a) and Cytb gene (Fig. 4b) were successfully amplified by PCR. All positive controls were successfully amplified, confirming that the PCRs were performing properly.

\section{Discussion}

Our negative findings across five viral families associated with emerging and re-emerging zoonotic diseases in recent decades in these throat and rectal swabs indicate the absence of viral shedding, and contrast with reports of the detection of parainfluenza virus (Wang et al. 2018), coronaviruses and Sendai virus (Liu et al. 2019; Zhang et al. 2020), and SARSr-CoVs (Lam et al. 2020; Xiao et al. 2020) in Sunda pangolins. Our sample size is substantial, particularly given the rarity of these animals in Malaysia-the International Union for Conservation of Nature (IUCN) lists the Sunda pangolin (Manis javanica) as 'Critically Endangered', as a result of poaching, smuggling and habitat loss (IUCN 2018). Our previous studies of bat coronaviruses revealed 5-10\% PCR prevalence (Yang et al. 2016; Anthony et al. 2017; Hu et al. 2017; Latinne et al. 2020), suggesting that even at the upper limit of the $95 \%$ confidence interval, our negative findings in pangolins are inconsistent with coronavirus shedding and endemic coronavirus infection at a population level. Serologic studies are needed to support this contention. Although the RNA had low purity and concentration (Table 3), we repeatedly detected coronaviruses using the same protocols in bat samples that had similar RNA purity and concentration and had been stored for $>5$ years (Table 4 ) as part of the PREDICT project (PREDICT Consortium 2017; PREDICT Consortium 2019). We are confident that the 
Table 1. PCR Conditions and Primer Sequences Used.

\begin{tabular}{|c|c|c|c|}
\hline $\begin{array}{l}\text { Target gene and } \\
\text { product length }\end{array}$ & Primers & Conditions & Reference \\
\hline $\begin{array}{l}\text { Cytochrome c } \\
\text { oxidase subunit } \\
\text { I gene } \\
750 \mathrm{bp}\end{array}$ & $\begin{array}{l}\text { BatL5310 F: CCTACTCRGCCATTTTACCTATG } \\
\text { R6036R R: ACTTCTGGGTGTCCAAAGAATCA }\end{array}$ & $\begin{array}{l}94^{\circ} \mathrm{C} \text { for } 5 \mathrm{~min} \text {, then } 35 \text { cycles of } 94^{\circ} \mathrm{C} \text { for } \\
30 \mathrm{~s}, 48^{\circ} \mathrm{C} \text { for } 45 \mathrm{~s} \text { and } \\
72^{\circ} \mathrm{C} \text { for } 90 \mathrm{~s} \text {. Finish with } 72^{\circ} \mathrm{C} \text { for } 10 \mathrm{~min}\end{array}$ & $\begin{array}{l}\text { Robins et al. } \\
\text { (2007) }\end{array}$ \\
\hline $\begin{array}{l}\text { Cytochrome b } \\
\text { mitochondrial } \\
\text { gene } \\
\sim 457 \text { bp }\end{array}$ & $\begin{array}{l}\text { Cytb F: GAGGMCAAATATCATTCTGAGG } \\
\text { Cytb R: } \\
\text { TAGGGCVAGGACTCCTCCTAGT }\end{array}$ & $\begin{array}{l}95^{\circ} \mathrm{C} \text { for } 2 \mathrm{~min} \text {, then } 50 \text { cycles of } 94^{\circ} \mathrm{C} \text { for } \\
30 \mathrm{~s}, 52^{\circ} \mathrm{C} \text { for } 50 \mathrm{~s} \text { and } \\
71^{\circ} \mathrm{C} \text { for } 1 \mathrm{~min} \text {. Finish with } 72^{\circ} \mathrm{C} \text { for } \\
7 \mathrm{~min}\end{array}$ & $\begin{array}{l}\text { Townzen } \\
\text { et al. } \\
(2008)\end{array}$ \\
\hline $\begin{array}{l}\text { Coronaviridae } \\
\text { RNA-Dependent } \\
\text { RNA Poly- } \\
\text { merase (RdRp) } \\
\text { First Round: } \\
520 \text { bp } \\
\text { Second Round: } \\
328 \text { bp }\end{array}$ & $\begin{array}{l}\text { Round 1: } \\
\text { CoV-FWD1: CGTTGGIACWAAYBTVCCWYTI- } \\
\text { CARBTRGG } \\
\text { CoV-RVS1: GGTCATKA- } \\
\text { TAGCRTCAVMASWWGCNACATG } \\
\text { Round 2: } \\
\text { CoV-FWD2: GGCWCCWCCHGGNGARCAATT } \\
\text { CoV-RVS2: GGWAWCCCCAYTGYTGWAYRTC }\end{array}$ & $\begin{array}{l}95^{\circ} \mathrm{C} \text { for } 5 \mathrm{~min} \text {, then } 40 \text { cycles of } 96^{\circ} \mathrm{C} \text { for } \\
5 \mathrm{~s}, 60^{\circ} \mathrm{C} \text { for } 8 \mathrm{~s} \text { and } \\
68^{\circ} \mathrm{C} \text { for } 15 \mathrm{~s} \text {. Finish with } 72^{\circ} \mathrm{C} \text { for } 2 \mathrm{~min} \\
\text { Same protocol for rounds } 2 \text { but for } 35 \\
\text { cycles. Designed to be used with Fast- } \\
\text { Cycling PCR kit }\end{array}$ & $\begin{array}{l}\text { Quan et al. } \\
\qquad(2010)\end{array}$ \\
\hline $\begin{array}{l}\text { Coronaviridae } \\
\text { RdRp } \\
\text { First Round: } \\
\quad 440 \text { bp } \\
\text { Second Round: } \\
\quad 434 \text { bp }\end{array}$ & $\begin{array}{l}\text { Round 1: } \\
\text { CoV-FWD3: GGTTGGGAYTAYCCHAARTGTGA } \\
\text { CoV-RVS3: CCATCATCASWYRAATCATCATA } \\
\text { Round 2: } \\
\text { CoV-FWD4/Other: GAY- } \\
\text { TAYCCHAARTGTGAUMGWGC } \\
\text { CoV-RVS3: CCATCATCASWYRAATCATCATA }\end{array}$ & $\begin{array}{l}95^{\circ} \mathrm{C} \text { for } 5 \mathrm{~min} \text {, then } 40 \text { cycles of } 96^{\circ} \mathrm{C} \text { for } \\
5 \mathrm{~s}, 60^{\circ} \mathrm{C} \text { for } 8 \mathrm{~s} \text { and } \\
68^{\circ} \mathrm{C} \text { for } 12 \mathrm{~s} \text {. Finish with } 72^{\circ} \mathrm{C} \text { for } 2 \mathrm{~min} \\
\text { Same protocol for rounds } 1 \text { and } 2 . \text { De- } \\
\text { signed to be used with Fast-Cycling PCR } \\
\text { kit }\end{array}$ & $\begin{array}{l}\text { Modified } \\
\text { from } \\
\text { Watanabe } \\
\text { et al. } \\
\text { (2010) }\end{array}$ \\
\hline $\begin{array}{l}\text { Filoviridae } \\
\text { L-Gene } \\
\text { First Round: } \\
\quad 680 \mathrm{bp}\end{array}$ & $\begin{array}{l}\text { Round 1: } \\
\text { Filo-MOD-FWD: TITTYTCHVTICAAAAICAYTGGG } \\
\text { FiloL.conR: ACCATCATRTTRCTIGGRAAKGCTTT } \\
\text { Round 2: }\end{array}$ & $\begin{array}{l}94^{\circ} \mathrm{C} \text { for } 5 \mathrm{~min} \text {, followed by } 40 \text { cycles of } \\
94^{\circ} \mathrm{C} \text { for } 1 \mathrm{~min}, 52^{\circ} \mathrm{C} \text { for } 1 \mathrm{~min} \text { and } \\
72^{\circ} \mathrm{C} \text { for } 1 \mathrm{~min} \text {. Finish with a final } \\
\text { extension of } 72^{\circ} \mathrm{C} \text { for } 7 \mathrm{~min}\end{array}$ & $\begin{array}{l}\text { Zhai et al. } \\
\text { (2007) }\end{array}$ \\
\hline $\begin{array}{l}\text { Second Round: } \\
630 \text { bp }\end{array}$ & $\begin{array}{l}\text { Filo-MOD-FWD: TITTYTCHVTICAAAAICAYTGGG } \\
\text { Filo-MOD-RVS: GCYTCISMIAIIGTTTGIACATT }\end{array}$ & Same protocol for rounds 1 and 2 & \\
\hline $\begin{array}{l}\text { Flaviviridae } \\
\text { NS5 gene } \\
\sim 270 \mathrm{bp}\end{array}$ & $\begin{array}{l}\text { Flavi-FWD: TGYRTBTAYAACATGATGGG } \\
\text { Flavi-RVS: GTGTCCCAICCNGCNGTRTC }\end{array}$ & $\begin{array}{l}95^{\circ} \mathrm{C} \text { for } 5 \mathrm{~min} \text { followed by } 45 \text { cycles of } \\
94^{\circ} \mathrm{C} \text { for } 15 \mathrm{~s}, 50^{\circ} \mathrm{C} \text { for } 30 \mathrm{~s}, 72^{\circ} \mathrm{C} \text { for } \\
45 \mathrm{~s} \text {, and } 77^{\circ} \mathrm{C} \text { for } 15 \mathrm{~s} \text {. Finish with } 72^{\circ} \mathrm{C} \\
\text { for } 10 \mathrm{~min}\end{array}$ & $\begin{array}{l}\text { Moureau } \\
\text { et al. } \\
(2007)\end{array}$ \\
\hline $\begin{array}{l}\text { Orthomyxoviridae } \\
\text { M gene } \\
243 \mathrm{bp}\end{array}$ & $\begin{array}{l}\text { FLUAV-M-U44: GTCTTCTAACCGAGGTCGAAACG } \\
\text { FLUAV-M-L287: GCATTTTGGACAAAGCGTCTACG }\end{array}$ & $\begin{array}{l}94^{\circ} \mathrm{C} \text { for } 2 \mathrm{~min} \text {, then } 45 \mathrm{cycles} \text { of } 94^{\circ} \mathrm{C} \text { for } \\
30 \mathrm{~s}, 52^{\circ} \mathrm{C} \text { for } 30 \mathrm{~s} \text { and } 72^{\circ} \mathrm{C} \text { for } 30 \mathrm{~s} \text {. } \\
\text { Finish with } 72^{\circ} \mathrm{C} \text { for } 7 \mathrm{~min}\end{array}$ & $\begin{array}{l}\text { Anthony } \\
\text { et al. } \\
\text { (2012) }\end{array}$ \\
\hline
\end{tabular}


Table 1. continued

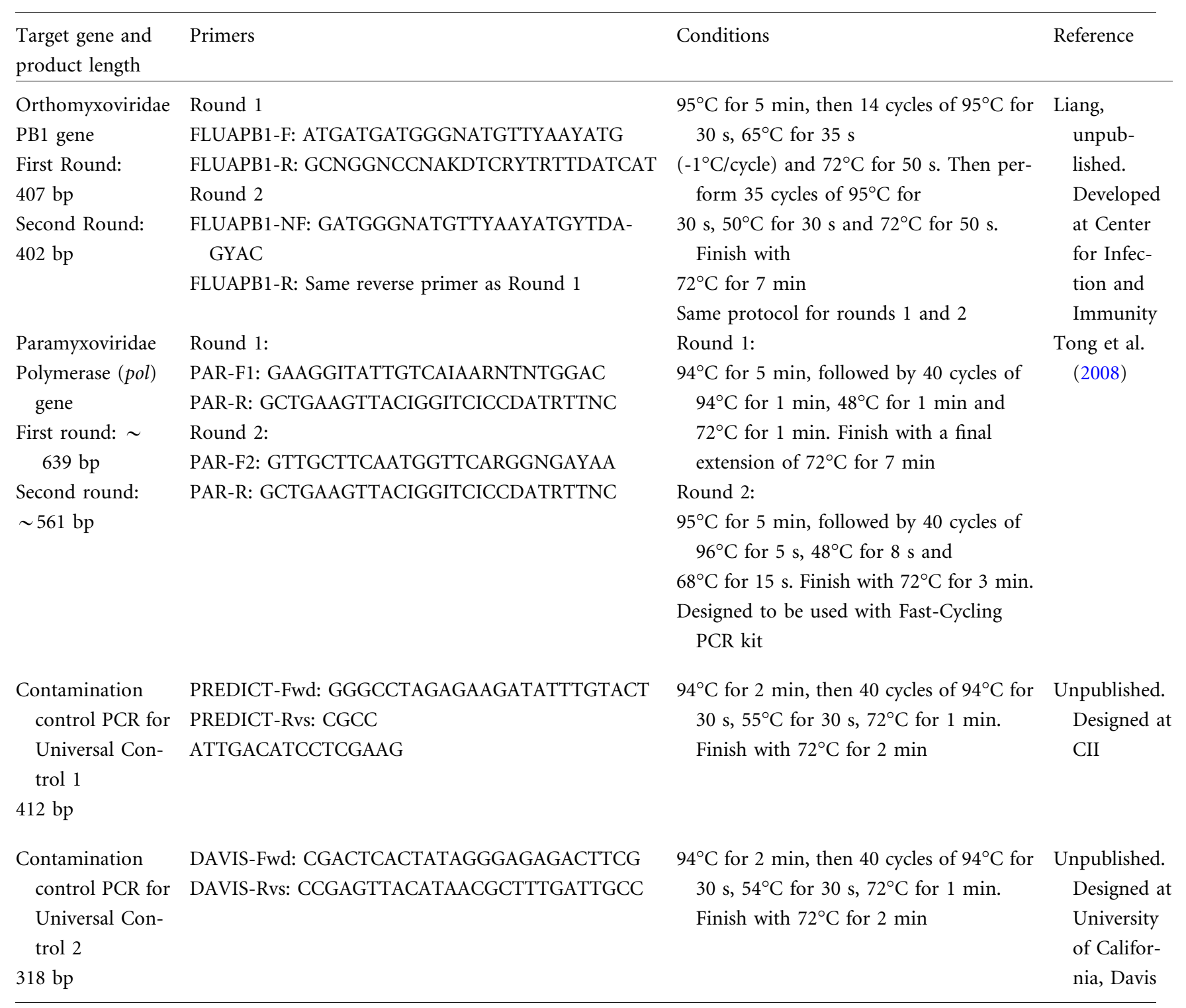

PCR protocols were sensitive and robust and that if coronaviruses had been present in these samples at the same viral load, they would have detected them.

While our sampling was necessarily opportunistic (given the conservation status and the cryptic nature of the species) and sampling intensity varied, our negative findings over ten years and at multiple locations support the veracity of the findings. The most parsimonious explanation for the contrast between our findings and the discovery of SARSr-CoVs in Sunda pangolins by (Liu et al. 2019, 2020; Lam et al. 2020; Xiao et al. 2020; Zhang et al. 2020) is the nature of the sampled population: our samples were drawn from an 'upstream' cohort of animals yet to enter or just entering the illegal trade network, whereas all others were drawn from 'downstream' cohorts confiscated at their destination in China. During the wildlife trade transits, which often includes movement through other Southeast Asian countries, animals are often housed together in groups from disparate geographic regions, and often with other species, giving opportunity for viral transmission among and within species. This is supported by data from bamboo rats in the wildlife market chain in Vietnam that had increasing prevalence of coronaviruses as they moved from traders, to large markets, to restaurants, concomitant with length of time in the wildlife trade (Huong et al. 2020). The housing of some of the animals in rehabilitation centres in China would also allow for exposure to coronaviruses from other groups or species. In 


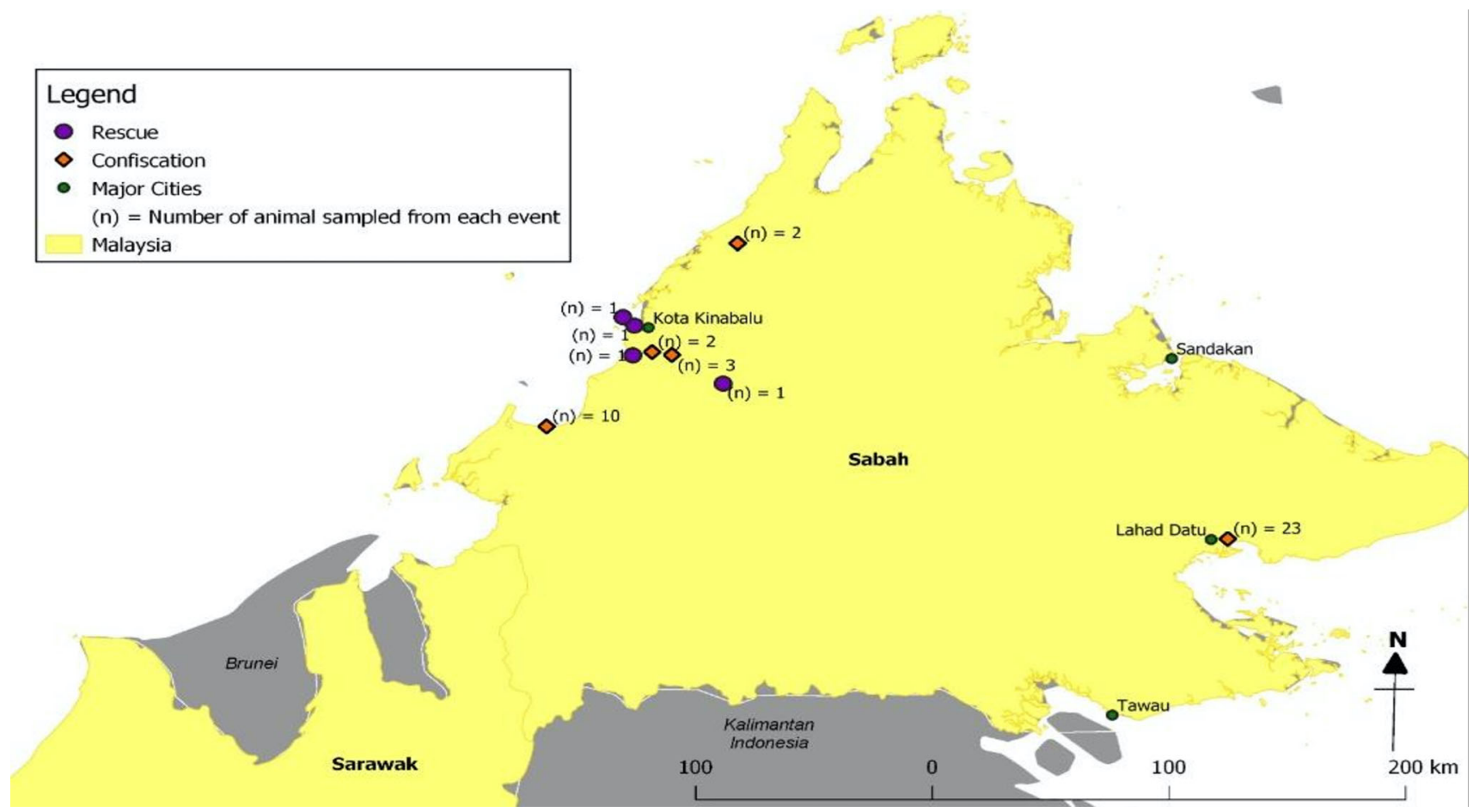

Figure 3. Locations where pangolins were rescued and confiscated in Sabah state.

natural wildlife reservoir hosts, SARSr-CoVs appear to cause little if any clinical signs, and this is supported by the limited laboratory infections so far carried out (Watanabe et al. 2010). The reports of clinical illness and pathology associated with coronavirus infection in pangolins (Liu et al. 2019; Xiao et al. 2020) are unlikely in a reservoir host. We therefore conclude that the detections of SARS-CoV-2related viruses in pangolins are more plausibly a result of their exposure to infected people, wildlife or other animals after they entered the trade network. Thus, the likelihood is that Sunda pangolins are incidental rather than reservoir hosts of coronaviruses as claimed by Zhang et al. (2020).

Our microsatellite DNA fragment analysis (manuscript in preparation) suggests that confiscated pangolins from Peninsular Malaysia and Sabah were taken from Malaysia, Brunei or Indonesia; however, further analysis of pangolins from the neighbouring countries is required to confirm the results. They were confiscated at holding facilities, ports or borders prior to shipment, and had not yet been exposed to multiple potential sources of infection, unlike the confiscated animals in China reported by Xiao et al. (2020) and Lam et al. (2020). An array of pathogens and infections have been observed in wet markets, in wildlife (Dong et al. 2007; Cantlay et al. 2017), in humans (Xu et al. 2004) and in domestic animals (Karesh et al. 2005). In comparison with wildlife screened from the wild (Poon et al. 2004) and from farms (Tu et al. 2004; Kan et al. 2005), wildlife in markets have a much higher chance of exposure to pathogens and disease spillover. These findings highlight the importance of carefully and systemically ending the trade in wildlife and improving biosecurity to avoid having wet markets where wild animals are mixing with farmed animals and humans.

Our findings suggest that pangolins that have not entered the illegal wildlife trade pose no threat to human health. While the detection of SARS-CoV-2 like viruses in some trade-rescued pangolins suggests a parallel with traded civets (Parguma larvata) in the emergence of SARS$\mathrm{CoV}$ (Guan et al. 2003), any role as an intermediate host in the transmission of SARS-CoV-2 from a putative natural bat host to humans is yet to be established. It is also important to note that phylogenetic comparison of the whole genomes and the RdRp sequence of the SARSr-CoVs sequenced from pangolins suggests that these are recombinants between a bat and a pangolin $\mathrm{CoV}$ and that there are two other bat-CoVs that are more closely related to SARS-CoV-2 (Latinne et al. 2020). Serological studies in pre-trade pangolins will shed further light on any role of pangolins as hosts of SARS-CoV-2-related viruses. All pangolin species face known and significant threats to their survival in nature and require active conservation efforts to ensure their enduring existence for future generations. 
Table 2. Details of Sunda pangolins.

\begin{tabular}{|c|c|c|c|}
\hline No. & Location & Date & Interface \\
\hline \multicolumn{4}{|c|}{ (a) Rescued from the wild in Peninsular Malaysia } \\
\hline 1 & $(* *)$ Kuantan, Pahang $(n=1)$ & $11 / 07 / 2018$ & Rescued from wild \\
\hline 2 & $(* *)$ Bentong, Pahang $(n=1)$ & $29 / 09 / 2018$ & Rescued from wild \\
\hline 3 & $\left({ }^{*}\right)$ Kuantan, Pahang $(n=1)$ & $25 / 03 / 2019$ & Rescued from wild \\
\hline \multicolumn{4}{|c|}{ (b) Confiscated from Peninsular Malaysia } \\
\hline 1 & $\left.{ }^{*}\right)$ Kedah $(n=65)$ & $27 / 08 / 2009$ & Confiscation \\
\hline 2 & $\left({ }^{*}\right)$ Kelantan $(n=73)$ & $09 / 09 / 2009$ & Confiscation \\
\hline 3 & $\left.{ }^{\star}\right)$ Johor $(n=18)$ & $30 / 09 / 2009$ & Confiscation \\
\hline 4 & $\left(^{\star}\right)$ Johor $(n=2)$ & $06 / 11 / 2009$ & Confiscation \\
\hline 5 & $\left.{ }^{\star}\right)$ Johor $(n=40)$ & $07 / 11 / 2009$ & Confiscation \\
\hline 6 & $\left(^{\star}\right)$ Johor $(n=45)$ & $06 / 04 / 2010$ & Confiscation \\
\hline 7 & $\left.{ }^{\star}\right)$ Pulau Pinang $(n=30)$ & $27 / 04 / 2010$ & Confiscation \\
\hline 8 & $\left.{ }^{\star}\right)$ Johor $(n=13)$ & $22 / 07 / 2010$ & Confiscation \\
\hline \multicolumn{4}{|c|}{ (c) Rescued from the wild in Sabah state } \\
\hline 1 & $(* *)$ Tambunan $(n=1)$ & $17 / 06 / 2015$ & Rescued from wild \\
\hline 2 & $\left.{ }^{(* *}\right)$ Kota Kinabalu $(n=1)$ & $01 / 05 / 2016$ & Rescued from wild \\
\hline 3 & $(* *)$ Penampang $(n=1)$ & $07 / 06 / 2016$ & Rescued from wild \\
\hline 4 & $\left.{ }^{(* *}\right)$ Kota Kinabalu $(n=1)$ & $21 / 02 / 2017$ & Rescued from wild \\
\hline 5 & $(* *)$ Penampang $(n=1)$ & $18 / 01 / 2018$ & Rescued from wild \\
\hline \multicolumn{4}{|c|}{ (d) Confiscated from Sabah state } \\
\hline 1 & $\left({ }^{\star *}\right)$ Beaufort $(n=10)$ & $31 / 10 / 2014$ & Confiscation \\
\hline 2 & $\left({ }^{* *}\right)$ Kota Belud $(n=2)$ & $18 / 09 / 2015$ & Confiscation \\
\hline 3 & $(* *)$ Lahad Datu $(n=23)$ & $22 / 02 / 2016$ & Confiscation \\
\hline 4 & $(* *)$ Penampang $(n=2)$ & $29 / 11 / 2016$ & Confiscation \\
\hline 5 & $(* *)$ Sandakan $(n=3)$ & $26 / 09 / 2017$ & Confiscation \\
\hline
\end{tabular}

(a), (b), (c) and (d) Details of Sunda pangolins confiscated from smugglers and rescued from wild. (Level of detail for the location of confiscations and rescue events reported was determined by the local wildlife departments).

(n) indicates the total number of pangolins sampled in the event.

$(\star)$ indicates the state where the confiscation or rescue occurred in Peninsular Malaysia.

$(\star \star)$ indicates the district where the confiscation or rescue occurred in Peninsular Malaysia or Sabah state. 
Table 3. RNA Purity and Concentration for a Subset of Pangolin Samples Accessed by Using Nanodrop Spectrophotometer.

\begin{tabular}{|c|c|c|c|c|c|c|}
\hline No. & Sample ID & Nucleic acid $(\mathrm{ng} / \mu \mathrm{L})$ & $\mathrm{A} 260(\mathrm{~nm})$ & $\mathrm{A} 280(\mathrm{~nm})$ & $260 / 280(\mathrm{~nm})$ & Factor \\
\hline 1 & ZEN00950T & 1.1 & 0.027 & 0.036 & 0.13 & 40 \\
\hline 2 & ZEN00950R & 6.7 & 0.168 & 0.148 & 2.07 & 40 \\
\hline 3 & ZEN00951T & 4.3 & 0.108 & 0.115 & 1.11 & 40 \\
\hline 4 & ZEN00951R & 19.7 & 0.493 & 0.365 & 1.16 & 40 \\
\hline 5 & ZEN00952T & 3.6 & 0.091 & 0.092 & 1.08 & 40 \\
\hline 6 & ZEN00952R & 20.0 & 0.500 & 0.343 & 3.08 & 40 \\
\hline 7 & ZEN00953T & 5.8 & 0.146 & 0.159 & 1.12 & 40 \\
\hline 8 & ZEN00953R & 11.5 & 0.287 & 0.194 & 2.68 & 40 \\
\hline 9 & ZEN00954T & 3.2 & 0.079 & 0.096 & 0.33 & 40 \\
\hline 10 & ZEN00954R & 3.6 & 0.090 & 0.088 & 0.34 & 40 \\
\hline 11 & ZEN00955T & 5.3 & 0.133 & 0.118 & 0.52 & 40 \\
\hline 12 & ZEN00955R & 36.1 & 0.902 & 0.573 & 1.01 & 40 \\
\hline 13 & ZEN00956T & 9.2 & 0.230 & 0.25 & 0.52 & 40 \\
\hline 14 & ZEN00956R & 6.2 & 0.154 & 0.116 & 1.21 & 40 \\
\hline 15 & ZEN00957T & 0.9 & 0.024 & 0.042 & 0.07 & 40 \\
\hline 16 & ZEN00957R & 13.9 & 0.347 & 0.255 & 4.21 & 40 \\
\hline 17 & ZEN00958T & 9.3 & 0.232 & 0.213 & 1.28 & 40 \\
\hline 18 & ZEN00958R & 11.5 & 0.287 & 0.184 & 2.18 & 40 \\
\hline 19 & ZEN00959T & 5.2 & 0.130 & 0.162 & 1.63 & 40 \\
\hline 20 & ZEN00959R & 11.8 & 0.296 & 0.321 & 2.26 & 40 \\
\hline 21 & ZEN00960T & 8.8 & 0.220 & 0.241 & 1.00 & 40 \\
\hline 22 & ZEN00960R & 15.1 & 0.377 & 0.324 & 2.16 & 40 \\
\hline 23 & ZEN00961T & 12.1 & 0.303 & 0.356 & 1.54 & 40 \\
\hline 24 & ZEN00961R & 13.0 & 0.728 & 0.532 & 1.23 & 40 \\
\hline 25 & ZEN00962T & 29.1 & 0.325 & 0.234 & 0.88 & 40 \\
\hline 26 & ZEN00962R & 17.0 & 0.426 & 0.319 & 0.88 & 40 \\
\hline 27 & ZEN00963T & 13.2 & 0.331 & 0.317 & 0.79 & 40 \\
\hline 28 & ZEN00963R & 6.6 & 0.166 & 0.115 & 1.16 & 40 \\
\hline 29 & ZEN00964T & 1.7 & 0.044 & 0.074 & 0.11 & 40 \\
\hline 30 & ZEN00964R & 6.5 & 0.162 & 0.143 & 0.56 & 40 \\
\hline
\end{tabular}



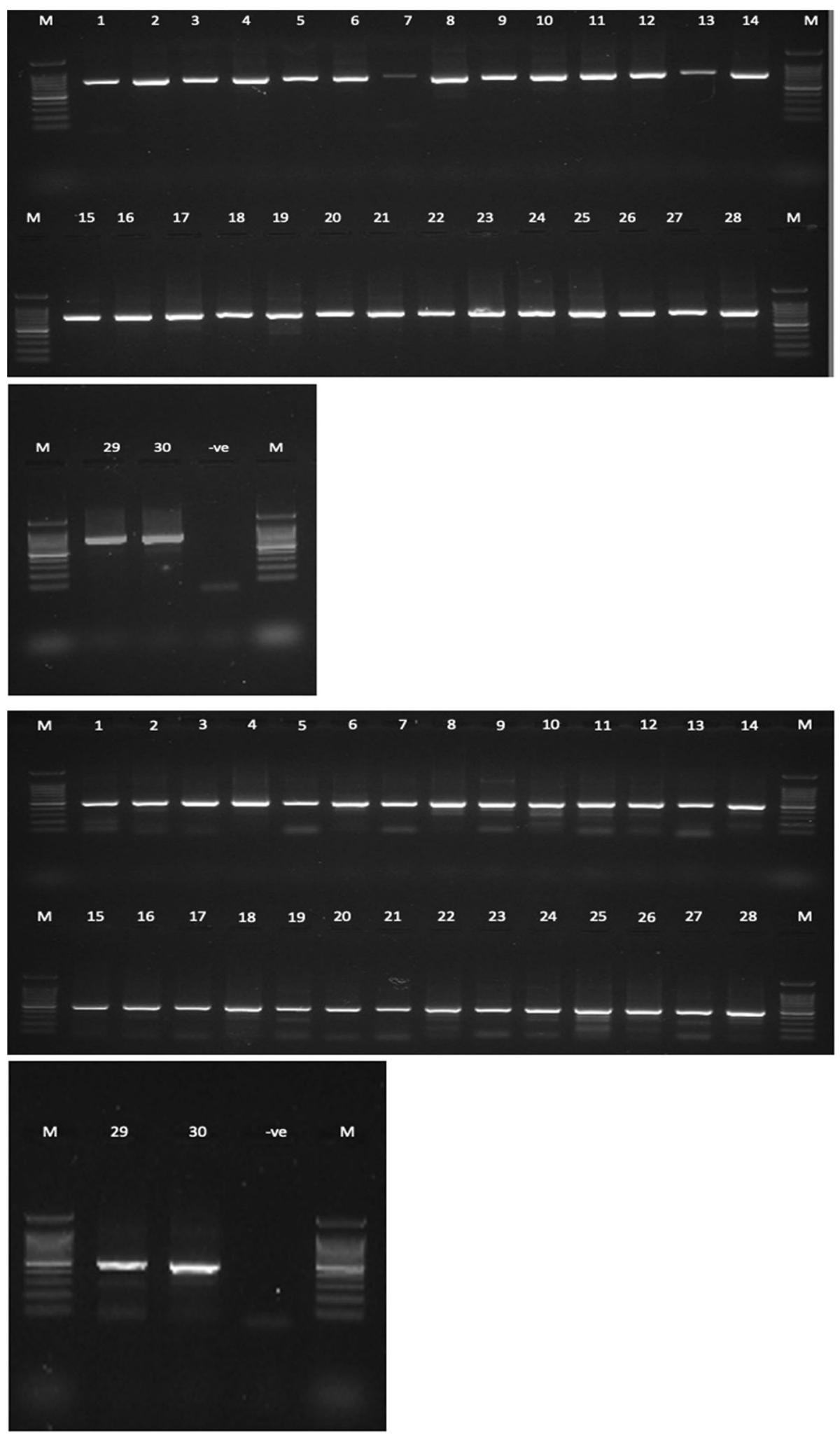
4Figure 4. a $1 \%$ agarose gel electrophoresis of PCR targeting on cytochrome $c$ oxidase subunit I gene for a subset of pangolin samples. [Lane M: 100 bp DNA ladder; Lane 1-ZEN00950T, Lane 2-ZEN00950R, Lane 3-ZEN00951T, Lane 4-ZEN00951R, Lane 5-ZEN00952T, Lane 6-ZEN00952R, Lane 7-ZEN00953T, Lane 8-ZEN00953R, Lane 9-ZEN00954T, Lane 10-ZEN00954R, Lane 11-ZEN00955T, Lane 12-ZEN00955R, Lane 13-ZEN00956T, Lane 14-ZEN00956R, Lane 15-ZEN00957T, Lane 16ZEN00957R, Lane 17-ZEN00958T, Lane 18-ZEN00958R, Lane 19-ZEN00959T, Lane 20-ZEN00959R, Lane 21-ZEN00960T, Lane 22-ZEN00960R, Lane 23-ZEN00961T, Lane 24ZEN00961R, Lane 25-ZEN00962T, Lane 26-ZEN00962R, Lane 27-ZEN00963T, Lane 28-ZEN00963R, Lane 29-ZEN00964T, Lane 30-ZEN00964R, Lane (-ve): Negative control]. b 1\% agarose gel electrophoresis of PCR targeting on cytochrome $b$ gene for $a$ subset of pangolin samples. [Lane M: 100 bp DNA ladder; Lane 1ZEN00950T, Lane 2-ZEN00950R, Lane 3-ZEN00951T, Lane 4ZEN00951R, Lane 5-ZEN00952T, Lane 6-ZEN00952R, Lane 7ZEN00953T, Lane 8-ZEN00953R, Lane 9-ZEN00954T, Lane 10ZEN00954R, Lane 11-ZEN00955T, Lane 12-ZEN00955R, Lane 13-ZEN00956T, Lane 14-ZEN00956R, Lane 15-ZEN00957T, Lane 16-ZEN00957R, Lane 17-ZEN00958T, Lane 18ZEN00958R, Lane 19-ZEN00959T, Lane 20-ZEN00959R, Lane 21-ZEN00960T, Lane 22-ZEN00960R, Lane 23-ZEN00961T, Lane 24-ZEN00961R, Lane 25-ZEN00962T, Lane 26ZEN00962R, Lane 27-ZEN00963T, Lane 28-ZEN00963R, Lane 29-ZEN00964T, Lane 30-ZEN00964R, Lane (-ve): Negative control].

\section{ACKNOWLEDGEMENTS}

We thank the Malaysian Government, particularly the Wildlife Disease Surveillance Programme of the Department of Wildlife and National Parks Peninsular Malaysia, Ministry of Health Malaysia, Department of Veterinary Services Malaysia, Sabah State Health Department, Universiti Malaysia Sabah, Sabah Wildlife Department, Sabah Wildlife Health Unit and Sabah Wildlife Rescue Unit. We thank Dato' Abdul K.A. Hashim, Rahmat Topani, Augustine Tuuga and Jum R.A. Sukor for their permission and support to conduct this research. We thank members of the EcoHealth Alliance Malaysia/Conservation Medicine field team (Dr. Zahidah Zeid, Mohamed S.M. Azian, Alexter Japrin, Ronald H.M. Tinggu, Muhammad Y. Wazlan, Nor A. Aziz) and Sabah Wildlife Rescue Unit and Wildlife Health Unit (Andrew Ginsos, Runie David and Leonorius bin Lojivis) for assistance with sample collection, we thank members of the EcoHealth Alliance Malaysia/Conservation Medicine laboratory team (Suraya Hamid, Nur A.M. Sungif) for sample processing at the Molecular Diagnostic Laboratory, at the Department of Wildlife and National Parks Peninsular Malaysia's National Wildlife Forensic Laboratory and we thank members of the EcoHealth Alliance Malaysia/Conservation Medicine laboratory team (Fernandes Opook, Emilly Sion) for sample processing at Sabah Wildlife Department's Wildlife Health, Genetic and Forensic Laboratory the EcoHealth Alliance Malaysia/ Conservation Medicine Program Assistant Velsri Sharminie

Table 4. RNA Purity and Concentration for a Subset of Bat Samples (Tested PCR Positive) Accessed by Using Nanodrop Spectrophotometer.

\begin{tabular}{|c|c|c|c|c|c|c|}
\hline No. & Sample ID & Nucleic acid $(n g / \mu L)$ & $\mathrm{A} 260(\mathrm{~nm})$ & A280 (nm) & $260 / 280(\mathrm{~nm})$ & Factor \\
\hline 1 & PMW01285T & 15.1 & 0.377 & 0.274 & 1.38 & 40 \\
\hline 2 & PMW01285R & 5.7 & 0.143 & 0.132 & 1.08 & 40 \\
\hline 3 & PMW01288T & 2.5 & 0.064 & 0.063 & 1.00 & 40 \\
\hline 4 & PMW01288R & 26.8 & 0.67 & 0.496 & 1.35 & 40 \\
\hline 5 & PMW01455T & 10.0 & 0.249 & 0.269 & 0.93 & 40 \\
\hline 6 & PMW01455R & 5.7 & 0.143 & 0.135 & 1.05 & 40 \\
\hline 7 & PMW01607T & 6.2 & 0.155 & 0.193 & 0.8 & 40 \\
\hline 8 & PMW01607R & 4.7 & 0.118 & 0.169 & 0.7 & 40 \\
\hline 9 & PMW01935T & 8.5 & 0.213 & 0.234 & 0.91 & 40 \\
\hline 10 & PMW01935R & 9.2 & 0.230 & 0.292 & 0.79 & 40 \\
\hline
\end{tabular}


for generating the maps. We dedicate this paper to Dr. Diana Ramirez, who sadly passed away on 31 October 2018, in honour of her vital contribution to this work and wildlife conservation in Sabah.

This study was made possible in part by the generous support of the American people through the United States Agency for International Development (USAID) Emerging Pandemic Threats PREDICT project (Cooperative Agreement number Cooperative Agreement Numbers AIDOAA-A-14-00102 and GHN-AOO-09-00010-00), and the USAID Infectious Disease Emergence and Economics of Altered Landscapes (IDEEAL) Project (Cooperative Agreement number AID-486-A-13-00005). The contents are the responsibility of the authors and do not necessarily reflect the views of USAID or the United States Government.

\section{Open Access}

This article is licensed under a Creative Commons Attribution 4.0 International License, which permits use, sharing, adaptation, distribution and reproduction in any medium or format, as long as you give appropriate credit to the original author(s) and the source, provide a link to the Creative Commons licence, and indicate if changes were made. The images or other third party material in this article are included in the article's Creative Commons licence, unless indicated otherwise in a credit line to the material. If material is not included in the article's Creative Commons licence and your intended use is not permitted by statutory regulation or exceeds the permitted use, you will need to obtain permission directly from the copyright holder. To view a copy of this licence, visit http://creativec ommons.org/licenses/by/4.0/.

\section{REFERENCES}

Andersen KG, Rambaut A, Lipkin WI, Holmes EC, Garry RF (2020) The proximal origin of SARS-CoV-2. Nature Medicine 26:450-452

Anthony SJ, Leger JS, Pugliares K, Ip HS, Chan JM, Carpenter ZW, Navarrete-Macias I, Sanchez-Leon M, Saliki JT, Pedersen J, Karesh W (2012) Emergence of fatal avian influenza in New England harbor seals. MBio. 3(4):e00166-12

Anthony SJ, Goldstein T, Rejmanek D, Sanchez MD, Seimon T, Fair J, Schneider B, Epstein J, Lipkin I (2013) Laboratory protocols for PREDICT surveillance

Anthony SJ, Johnson CK, Greig DJ, Kramer S, Che X, Wells H, Hicks AL, Joly DO, Wolfe ND, Daszak P, Karesh W, Lipkin WI,
Morse SS, Mazet JAK, Goldstein T (2017) Global patterns in coronavirus diversity. Virus Evolution 3:vex012-vex012.

Cantlay JC, Ingram DJ, Meredith AL (2017) A review of zoonotic infection risks associated with the wild meat trade in Malaysia. EcoHealth 14:361-388

Dong BQ, Liu W, Fan XH, Vijaykrishna D, Tang XC, Gao F, Li LF, Li GJ, Zhang JX, Yang LQ, Poon LLM, Zhang SY, Peiris JSM, Smith GJD, Chen H, Guan Y (2007) Detection of a novel and highly divergent coronavirus from Asian leopard cats and Chinese ferret badgers in Southern China. Journal of Virology 81:6920-6926

Guan Y, Zheng BJ, He YQ, Liu XL, Zhuang ZX, Cheung CL, Luo SW, Li PH, Zhang LJ, Guan YJ, Butt KM, Wong KL, Chan KW, Lim W, Shortridge KF, Yuen KY, Peiris JS, Poon LL (2003) Isolation and characterization of viruses related to the SARS coronavirus from animals in southern China. Science 302(5643):276-278

Hu B, Zeng LP, Yang XL, Ge XY, Zhang W, Li B, Xie JZ, Shen XR, Zhang YZ, Wang N, Luo DS, Zheng XS, Wang MN, Daszak P, Wang LF, Cui J, Shi ZL (2017) Discovery of a rich gene pool of bat SARS-related coronaviruses provides new insights into the origin of SARS coronavirus. PLoS Pathogens 13. https://doi.org/ 10.1371/journal.ppat.1006698. Online November 30, 2017

Huong NQ, Nga NTT, Long NV, Luu BD, Latinne A, Pruvot M, Phuong NT, Quang LTV, Hung VV, Lan NT, Hoa NT, Minh PQ, Diep NT, Tung N, Ky VD, Roberton SI, Thuy HB, Long NV, Gilbert M, Wicker L, Mazet JAK, Johnson CK, Goldstein T, Tremeau-Bravard A, Ontiveros V, Joly DO, Walzer C, Fine AE, Olson SH (2020) Coronavirus testing indicates transmission risk increases along wildlife supply chains for human consumption in Viet Nam, 2013-2014. PLoS ONE 15:e0237129

IUCN (2018) The IUCN Red List of Threatened Species. Version 2015.2, http://www.iucnredlist.org

Kan B, Wang M, Jing H, Xu H, Jiang X, Yan M, Liang W, Zheng H, Wan K, Liu Q, Cui B, Xu Y, Zhang E, Wang H, Ye J, Li G, Li M, Cui Z, Qi X, Chen K, Du L, Gao K, Zhao YT, Zou XZ, Feng YJ, Gao YF, Hai R, Yu D, Guan Y, Xu J (2005) Molecular evolution analysis and geographic investigation of severe acute respiratory syndrome coronavirus-like virus in palm civets at an animal market and farms. Virology 79(18):11892-11900

Karesh WB, Cook RA, Bennett EL, Newcomb J (2005) Wildlife trade and global disease emergence. Emerging Infectious Diseases. 11(7):1000-1002

Karesh WB (2010) Predict: surveillance and prediction for emerging pathogens of wildlife. BMX Proceeding 5(Suppl):L7

Ksiazek TG, Erdman D, Goldsmith CS, Zaki SR, Peret T, Emery S, Tong S, Urbani C, Comer JA, Lim W, Rollin PE, Dowell SF, Ling AE, Humphrey CD, Shieh WJ, Guarner J, Paddock CD, Rota P, Fields B, DeRisi J, Yang JY, Cox N, Hughes JM, LeDuc JW, Bellini WJ, Anderson LJ (2003) A novel coronavirus associated with severe acute reparatory syndrome. The New England Journal of Medicine 348:1953-1966

Lam TT-Y, Shum MH-H, Zhu H-C, Tong Y-G, Ni X-B, Liao Y-S, Wei W, Cheung WY-M, Li W-J, Li L-F, Leung GM, Holmes EC, Hu Y-L, Guan Y (2020) Identifying SARS-CoV-2 related coronaviruses in Malayan pangolins. Nature https://doi.org/10.1038/ s41586-020-2169-0. Online March 26, 2020

Latinne A, Hu B, Olival KJ, Zhu G, Zhang L, Li H, Chmura AA, Field HE, Zambrana-Torrelio C, Epstein JH, Li B, Zhang W, Wang L-F, Shi Z-L, Daszak P (2020) Origin and cross-species transmission of bat coronaviruses in China. Nature Communications 11:4235 
Lee J, McKibbin W (2004) Estimating the global economic costs of SARS. Institute of Medicine (US) Forum on Microbial Threats. Learning from SARS. Preparing for the next outbreak. Workshop summary. Washington DC: National Academies Press

Liu P, Chen W, Chen JP (2019) Viral metagenomic revealed sendai virus and coronavirus infection of Malayan pangolins (Manis javanica). Viruses 11(979); https://doi.org/10.3390/v11 110979 [Online October 24, 2019]

Liu P, Jiang JZ, Wan XF, Hua Y, Wang X, Hou F, Chen J, Zou J, Chen J (2020) Are pangolins the intermediate host of the 2019 novel coronavirus (2019-nCoV). bioRxiv https://doi.org/10.11 01/2020.02.18.954628 [Online February 20, 2020]

Moureau G, Temmam S, Gonzalez JP, Charrel RN, Grard G, De Lamballerie X (2007) A real-time RT-PCR method for the universal detection and identification of flaviviruses. Vector Borne Zoonotic Diseases 7(4):467-478

Nayar A (2009) Wildlife trade threatens southeast Asia's rare species. Nature. https://doi.org/10.1038/news.2009.1136. Online December 22, 2009

Poon LLM, Chu DKW, Chan KH, Wong OK, Ellis TM, Leung YHC, Lau SKP, Woo PCY, Suen KY, Yuen KY, Guan Y, Peiris JSM (2004) Identification of a novel coronavirus in bats. Virology 79(4):2001-2009

PREDICT Consortium. USAID PREDICT. www.predict.global. Available at: Accessed May 15, 2020.

PREDICT Consortium. PREDICT 1 \& PREDICT 2 Surveillance. Available at: https://www.healthmap.org/predict/. Accessed May 15, 2020.

Quan PL, Firth C, Street C, Henriquez JA, Petrosov A, Tashmukhamedova A, Hutchison SK, Egholm M, Osinubi MO, Niezgoda M, Ogunkoya $A B$ (2010) Identification of a severe acute respiratory syndrome coronavirus-like virus in a leafnosed bat in Nigeria. MBio 1(4):00208-00210

Robins JH, Hingston M, Matisoo-Smith E, Ross HA (2007) Identifying Rattus species using mitochondrial. DNA. 7(5):717729

Rosen GE, Smith KF (2010) Summarizing the evidence on the international trade in illegal wildlife. EcoHealth 7:24-32

Smith KF, Sax DF, Lafferty KD (2006) Evidence for the role of infectious disease in species extinction and endangerment. Conservation Biology 20:1349-1357

Smith KF, Behrens MD, Max LM, Daszak P (2008) U.S. drowning in unidentified fishes: Scope, implications, and regulation of live fish import. Conservation Letters: 103-109

Smith KF, Behrens M, Schloegel LM, Marano N, Burgiel S, Daszak P (2009) Reducing the Risks of the Wildlife Trade. Science 324:594-595

Tong S, Chern SWW, Li Y, Pallansch MA, Anderson LJ (2008) Sensitive and broadly reactive reverse transcription-PCR assays to detect novel paramyxoviruses. Journal of Clinical Microbiology 46(8):2652-2658

Townzen JS, Brower AVZ, Judd DD (2008) Identification of mosquito bloodmeals using mitochondrial cytochrome oxidase subunit I and cytochrome b gene sequences. Journal of Medical and Veterinary Entomology 22(4):386-393
Tu CC, Crameri G, Kong XG, Chen JD, Sun YW, Yu M, Xiang H, Xia XZ, Liu SW, Ren T, Yu YD, Eaton BT, Xuan H, Wang LF (2004) Antibodies to SARS coronavirus in civets. Emerging Infectious Diseases 10(12):2244-2248

Wang LF, Eaton BT (2007) Bats, Civets and the emergence of SARS. Wildlife and Emerging Zoonotic Diseases: The Biology, Circumstances and Consequences of Cross-Species Transmission 315:325-344

Wang X, Chen W, Xiang R, Li L, Chen J, Zhong R, Xiang H, Chen $\mathrm{J}$ (2018) Complete genome sequence of parainfluenza virus 5 (PIV5) from a Sunda pangolin (Manis javanica) in China. Wildlife Diseases 55(4): https://doi.org/10.7589/2018-09-211

Watanabe S, Masangkay JS, Nagata N, Morikawa S, Mizutani T, Fukushi S, Alviola P, Omatsu T, Ueda N, Iha K, Taniguchi S, Fujii H, Tsuda S, Endoh M, Kato K, Tohya Y, Kyuwa S, Yoshikawa Y, Akashi H (2010) Bat coronaviruses and experimental infection of bats, the Philippines. Emerging Infectious Diseases 16(8):1217-1223

Xiao K, Zhai J, Feng Y, Zhou N, Zhang X, Zou JJ, Li N, Guo Y, Li X, Shen X, Zhang Z, Shu F, Huang W, Li Y, Zhang Z, Chen RA, Wu YJ, Peng SM, Huang M, Xie WJ, Cai QH, Hou FH, Liu Y, Chen W, Xiao L, Shen Y (2020) Isolation and characterization of 2019-nCoV-like coronavirus from Malayan pangolins. bioRxiv https://doi.org/10.1101/2020.02.17.951335. Online February 20, 2020

Xu H, Wang M, Zhang Z, Zou X, Gao Y, Liu X, Lu E, Pan B, Wu $S$, Yu S (2004) An epidemiologic investigation on infection with severe acute respiratory syndrome coronavirus in wild animal traders in Guangzhou. Zhonghua yu fang yi xue za zhi [Chinese Journal of Preventive Medicine] 38:81-83

Yang XL, Hu B, Wang B, Wang MN, Zhang Q, Zhang W, Wu LJ, Ge XY, Zhang YZ, Daszak P, Wang LF, Shi ZL (2016) Isolation and Characterization of a Novel Bat Coronavirus Closely Related to the Direct Progenitor of Severe Acute Respiratory Syndrome Coronavirus. Journal of Virology 90:3253-3256

Zhai J, Palacios G, Towner JS, Jabado O, Kapoor V, Venter M, Grolla A, Briese T, Paweska J, Swanepoel R, Feldmann H (2007) Rapid molecular strategy for filovirus detection and characterization. Journal Clinical Microbiology 45(1):224-226

Zhang T, Wu Q, Zhang Z (2020) Probable Pangolin Origin of SARS-CoV-2 Associated with the COVID-19 Outbreak. Current Biology 30:1346-1351.e1342

Zhou P, Yang X-L, Wang X-G, Hu B, Zhang L, Zhang W, Si H-R, Zhu Y, Li B, Huang C-L, Chen H-D, Chen J, Luo Y, Guo H, Jiang R-D, Liu M-Q, Chen Y, Shen X-R, Wang X, Zheng X-S, Zhao K, Chen Q-J, Deng F, Liu L-L, Yan B, Zhan F-X, Wang YY, Xiao G-F, Shi Z-L (2020) A pneumonia outbreak associated with a new coronavirus of probable bat origin. Nature 579:270273

Zhu N, Zhang D, Wang W, Li X, Yang B, Song J, Zhao X, Huang B, Shi W, Lu R, Niu P, Zhan F, Ma X, Wang D, Xu W, Wu G, Gao GF, Tan W, China Novel Coronavirus Investigating and Research Team (2020) A novel coronavirus from patients with pneumonia in China, 2019. New England Journal of Medicine 382(2):727-733 